\title{
PENGARUH VARIABEL MAKROEKONOMI DAN RASIO KEUANGAN TERHADAP HARGA SAHAM
}

\author{
Aldrian Bernard Wijaya ${ }^{1}$, Nuryasman $\mathrm{MN}^{2}$ \\ ${ }^{1}$ Program Studi Manajemen, Fakultas Ekonomi dan Bisnis, Universitas Tarumanagara \\ Email: aldrianbw121@gmail.com \\ ${ }^{2}$ Program Studi Manajemen, Fakultas Ekonomi dan Bisnis, Universitas Tarumanagara* \\ Email: nuryasman@fe.untar.ac.id \\ *Penulis Korespondensi
}

Masuk : 15-01-2022, revisi: 20-01-2022, diterima untuk diterbitkan : 25-01-2022

\begin{abstract}
ABSTRAK
Penelitian ini bertujuan untuk mengetahui apakah terdapat pengaruh dari tingkat inflasi, tingkat suku bunga, nilai tukar/kurs dan Return on Asset (ROA) terhadap harga saham perusahaan yang tergabung ke dalam Indeks LQ45 Bursa Efek Indonesia periode 2016-2020. Sampel penelitian ini adalah sebanyak 27 sampel yang dipilih berdasarkan metode purposive sampling. Data pada penelitian ini menggunakan data sekunder yang diperoleh dari situs Bursa Efek Indonesia, situs Bank Indonesia, situs Badan Pusat Statistik dan situs Yahoo Finance. Teknik analisis yang digunakan adalah analisis regresi data panel dengan menggunakan software Eviews9. Hasil Penelitian ini menunjukkan bahwa secara bersama-sama tingkat inflasi, tingkat suku bunga, nilai tukar/kurs dan Return on Asset (ROA) berpengaruh signifikan terhadap harga saham, sedangkan secara parsial hanya tingkat inflasi dan Return on Asset (ROA) yang memiliki pengaruh signifikan terhadap harga saham.
\end{abstract}

Kata Kunci: Harga Saham, Tingkat Inflasi, Tingkat Suku Bunga, Nilai Tukar/Kurs, Return on Asset (ROA)

\section{ABSTRACT}

The objective of thus research was to examine the effect of the inflation rate, interest rate, exchange rate and Return on Assets (ROA) on the stock prices of companies incorporated into the LQ45 Index of the Indonesia Stock Exchange for the 2016-2020 period. The sample of this research was 27 samples which were selected based on the purposive sampling method. The data in this study uses secondary data obtained from the Indonesia Stock Exchange website, the Bank Indonesia website, the Central Statistics Agency website and the Yahoo Finance website. The analysis technique used is panel data regression analysis using Eviews 9 software. The results of this study indicate that together the inflation rate, interest rate, exchange rate and Return on Assets (ROA) have a significant effect on stock prices. Meanwhile, partially, only the inflation rate and Return on Assets (ROA) have a significant effect on stock prices.

Keywords: Stock Prices, Inflation rate, Interest Rate, Exchange Rate, Return on Asset (ROA)

\section{PENDAHULUAN Latar Belakang}

Saat ini perkembangan ekonomi dunia sangat didominasi oleh pasar modal. Pasar modal adalah pasar tempat diperjualbelikannya berbagai instrumen keuangan jangka panjang, baik dalam bentuk utang (obligasi) maupun dalam bentuk ekuitas (saham). Pasar modal juga merupakan representasi untuk menilai kondisi perusahaan-perusahaan di suatu negara (Nuryasman \& Permatasari, 2016). Dari fungsi ekonomi, pasar modal berfungsi sebagai media bagi pihak yang kekurangan modal untuk mencari dana dan media bagi pihak yang memiliki kelebihan dana untuk berinvestasi. Investasi adalah komitmen atas sejumlah dana atau sumber daya lainnya yang 
dilakukan pada saat ini, dengan tujuan memperoleh keuntungan di masa yang akan datang (Syahyunan, 2015).

Bursa Efek Indonesia (BEI) memiliki 38 jenis indeks harga saham. Salah satu jenis indeks di bursa efek Indonesia adalah LQ45. Indeks LQ45 dapat menggambarkan dan mewakili pasar saham di Indonesia karena LQ45 mengukur kinerja dari 45 saham yang memiliki likuiditas dan kapitalisasi pasar yang besar serta didukung oleh fundamental perusahaan yang baik (IDX, 2021).

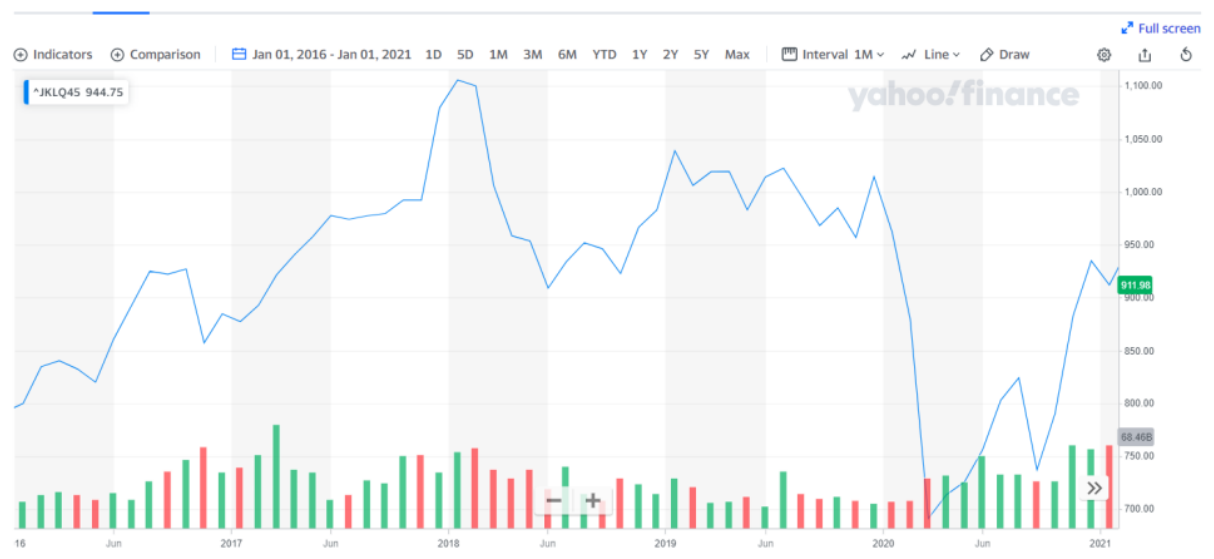

Gambar 1. Perkembangan Indeks LQ45 periode 2016-2020

Sumber: Yahoo Finance (2021)

Pada tahun 2016 sampai dengan awal tahun 2018, pergerakan indeks harga saham LQ45 terus berfluktuasi dengan kecenderungan naik hingga mencapai titik tertinggi pada bulan Januari 2018, yaitu sebesar 1.105,76. Akan tetapi setelah itu, indeks LQ45 cenderung mengalami penurunan, dan terjadi penurunan secara drastis, hingga pada bulan Maret 2020 mencapai titik nilai terendah, yaitu 691,13. Indeks harga saham LQ45 yang semula menunjukkan uptrend dari tahun 2016 sampai awal 2018, kemudian mengalami downtrend dan turun secara drastis pada tahun 2020. Diperkirakan hal ini dipengaruhi oleh faktor-faktor eksternal (makroekonomi) dan internal (mikro) dari perusahaan-perusahaan yang tergabung di dalam indeks LQ45. Faktor internal seperti kondisi dan kinerja perusahaan itu sendiri, sedangkan faktor eksternal adalah faktor makroekonomi secara keselurhan (Nuryasman \& Yessica, 2017).

Harga saham dipengaruhi oleh eksternal perusahaan, yaitu faktor makroekonomi seperti inflasi, suku bunga, dan nilai tukar/kurs. Sebaiknya investor mengetahui dan memahami kondisi makroekonomi ketika akan membuat keputusan investasi, termasuk investasi di pasar modal (Kurniasih \& Johannes, 2015). Kemudian, harga saham juga dipengaruh oleh faktor internal, yaitu rasio keuangan dan kinerja perusahaan itu sendiri yang sering digunakan untuk memprediksi harga saham (Ivan, 2018). Analisis ini bertujuan untuk memastikan bahwa saham yang akan dibeli merupakan saham dari perusahaan yang memiliki kinerja baik.

\section{Kajian teori}

Pada penelitian ini, dasar teori yang digunakan adalah Teori Sinyal, Teori Penilaian Saham, Capital Asset Pricing Model (CAPM), dan Arbitrage Pricing Theory (APT). Menurut Al-Sartawi dan Reyad (2018), teori sinyal mengasumsikan bahwa perusahaan yang efisien memberikan 
informasi yang relevan dan lebih baik kepada investor daripada perusahaan yang kurang efisien untuk meningkatkan modal. Laporan tahunan sebaiknya memberikan informasi yang penting dan relevan untuk diketahui baik pihak dalam maupun luar perusahaan. Teori Sinyal atau Signaling Theory adalah teori yang menjelaskan mengenai alasan suatu perusahaan mempunyai dorongan untuk memberikan informasi mengenai keuangan perusahaan kepada pihak luar. Penyebab suatu perusahaan untuk memberikan informasi karena adanya asimetris informasi antara perusahaan dengan pihak luar. Stiglitz (2000) menjelaskan bahwa "The signaling theory addresses information asymmetries between the management and stakeholders, where the sources of asymmetric information are largely concerned with information about intent or quality" artinya teori sinyal membahas asimetris informasi antara manajemen dan pemangku kepentingan, dimana sumber informasi asimetris sebagian besar berkaitan dengan informasi tentang maksud atau kualitas.

Dalam melakukan analisa penilaian saham, terdapat 2 pendekatan yang dapat digunakan, yaitu analisis teknikal dan analisis fundamental. Analisis teknikal adalah analisis yang dilihat dengan memperhatikan pergerakan harga saham. Analisis teknikal beranggapan bahwa harga suatu saham ditentukan oleh permintaan dan penawaran saham dari waktu ke waktu. Analisis fundamental adalah analisis sekuritas yang menggunakan data-data internal (fundamen) dan faktor-faktor eksternal yang berhubungan dengan perusahaan/ badan usaha tersebut (Andriani, 2013). Data fundamental yang dimaksud adalah data keuangan, data pangsa pasar, siklus bisnis, dan sejenisnya, sementara data faktor eksternal yang berhubungan dengan badan usaha adalah kebijakan pemerintah, tingkat suku bunga, inflasi, dan sejenisnya.

Capital Asset Pricing Model (CAPM) adalah teori penilaian resiko dan keuntungan asset yang didasarkan pada koefisien beta. CAPM merupakan suatu model yang menentukan harga suatu aset berdasarkan pada kondisi ekuilibrium (Juwana, 2015). Konsep CAPM pada umumnya berguna untuk mengidentifikasi hubungan antara risiko dan return. CAPM adalah teori penilaian risiko dan keuntungan aset yang didasarkan koefisien beta (indeks risiko yang tidak dapat didiversifikasi) terhadap pengaruh pasar (Ibrahim dkk., 2017).

Arbitrage Pricing Theory (APT) adalah teori yang mendasarkan diri pada konsep satu harga (the law of one price). Artinya, bahwa dua kesempatan investasi yang mempunyai karakteristik yang identik sama tidaklah bisa dijual dengan harga yang berbeda (hukum satu harga). Jika aktiva yang berkarakteristik sama tersebut dijual dengan harga yang berbeda, maka akan terdapat kesempatan untuk melakukan arbitrage, yaitu dengan membeli aktiva yang berharga murah dan menjualnya dengan harga yang lebih tinggi pada saat yang sama, sehingga dapat diperoleh return tanpa risiko. Melalui Arbitrage Pricing Theory (APT), telah dibuktikan bahwa variabelvariabel makroekonomi memiliki pengaruh sistematis terhadap tingkat pengembalian (return) pasar saham. Kekuatan ekonomi mempengaruhi tingkat diskonto (discount rate), kemampuan perusahaan untuk menggerakkan aliran kas (cash flow), dan pembayaran dividen di masa yang akan datang (future dividend payouts) (Chen, 1983).

Chang dkk. (2019) melakukan penelitian tentang hubungan antara faktor makroekonomi dengan indeks Karachi Stock Exchange (KSE-100), hasil penelitian menyebutkan bahwa pada jangka panjang, kurs dan suku bunga memiliki pengaruh negatif terhadap harga saham, akan tetapi indeks harga konsumen memiliki positif terhadap harga saham. Subing dkk. (2017) dalam penelitiannya menemukan bahwa Return on Asset (ROA) memiliki pengaruh positif terhadap 
harga saham, sedangkan inflasi berpengaruh negatif terhadap harga saham dan suku bunga tidak memiliki pengaruh. Hongbing dan Fadli (2020) dalam penelitiannya menemukan bahwa Return on Asset (ROA) tidak memiliki pengaruh terhadap harga saham. Utomo dkk. (2019) menemukan bahwa kurs dan inflasi memiliki pengaruh positif terhadap harga saham, sedangkan suku bunga memiliki pengaruh negatif. Saputra dkk. (2019) dalam penelitiannya menemukan bahwa Return on Asset (ROA) tidak memiliki pengaruh terhadap harga saham.

Berdasarkan latar belakang dan landasan teori, penelitian ini dilakukan karena terdapat fenomena pada pergerakan indeks LQ45 serta berbedanya hasil penelitian sebelumnya (research gap) yang dilakukan oleh beberapa peneliti terdahulu. Penelitian ini menguji pengaruh tingkat inflasi, tingkat suku bunga, nilai tukar/kurs dan Return on Asset (ROA) terhadap harga saham.

H1: terdapat pengaruh tingkat inflasi terhadap harga saham.

H2: terdapat pengaruh tingkat suku bunga terhadap harga saham.

H3: terdapat pengaruh nilai tukar/kurs terhadap harga saham.

H4: terdapat pengaruh Return on Asset (ROA) terhadap harga saham.

\section{METODE PENELITIAN}

Populasi pada penelitian ini adalah perusahaan-perusahaan yang tergabung ke dalam Indeks LQ45 BEI periode 2016-2020. Untuk sampel pada penelitian ini diambil dengan metode purposive sampling, yaitu pemilihan berdasarkan kriteria yang ditentukan peneliti. Beberapa kriteria yang ditetapkan sebagai berikut: (1) Perusahaan-perusahaan yang masuk ke indeks LQ45 mulai tahun 2016; (2) Perusahaan-perusahaan yang tidak keluar dari indeks LQ45 setelah tahun 2016; (3) Perusahaan-perusahaan tersebut menerbitkan laporan keuangan tahunan selama periode tahun 2016-2020; (4) Perusahaan-perusahaan tersebut laporan keuangan tahunannya memuat data yang diperlukan untuk penelitian selama periode tahun 2016-2020; (5) Data yang diperlukan tidak bernilai 0 atau kurang dari 0 selama periode tahun 2016-2020. Berdasarkan kriteria tersebut, terdapat 27 perusahaan yang menjadi sampel pada penelitian ini.

Subjek penelitian ini adalah harga saham perusahaan-perusahaan yang tergabung dalam indeks LQ45. Objek pada penelitian ini adalah tingkat inflasi, tingkat suku bunga, kurs, dan Return on Asset (ROA). Operasionalisasi dari variabel-variabel tersebut ditampilkan pada Tabel 1.

Tabel 1. Operasionalisasi variabel

\begin{tabular}{|l|l|c|}
\hline \multicolumn{1}{|c|}{ Variabel } & \multicolumn{1}{c|}{ Ukuran } & Skala \\
\hline Harga Saham (HS) & Harga saham penutupan pada 31 Desember selama periode penelitian. & Nominal \\
\hline Tingkat Inflasi (INF) & Tingkat inflasi pada bulan Desember selama periode penelitian. & Rasio \\
\hline Tingkat Suku Bunga (SB) & $\begin{array}{l}\text { BI 7 Days Reverse Repo Rate bulan Desember selama periode } \\
\text { penelitian. }\end{array}$ & Rasio \\
\hline Kurs/ Nilai Tukar (NT) & $\begin{array}{l}\text { Nilai tukar dolar Amerika Serikat terhadap rupiah pada 31 Desember } \\
\text { selama periode Penelitian. }\end{array}$ & Nominal \\
\hline Return on Asset (ROA) & ROA = Earning after tax & Total Asset \\
\hline
\end{tabular}

Data-data yang digunakan dalam penelitian ini diperoleh melalui situs www.idx.co.id, www.finance.yahoo.com, www.bps.go.id, dan www.bi.go.id. Situs-situs tersebut menyediakan data berupa perusahaan yang terdaftar di Indeks LQ45 Bursa Efek Indonesia (BEI), harga saham 
perusahaan, tingkat inflasi, tingkat suku bunga, kurs dan Return on Asset (ROA). Untuk melakukan analisa dan menguji data-data dalam penelitian ini, peneliti menggunakan program EViews 9.

Pada penelitian ini, data yang dianalisis dilakukan transformasi ke dalam bentuk logaritma natural karena satuan pada penelitian ini berbeda satu sama lain. Menurut Ghozali (2016), transformasi merupakan salah satu cara untuk menormalkan data dengan mengubah skala pengukuran data asli ke dalam bentuk lain yang masih memiliki nilai sama, sehingga dapat memenuhi kriteria uji asumsi klasik. Transformasi ini juga mempunyai tujuan untuk memperkecil koefisien yang dihasilkan pada penelitian karena adanya perbedaan satuan antar variabel yang sangat besar. Kemudian, uji statistik yang digunakan pada penelitian ini adalah uji multikolinieritas, uji statistik deskriptif, uji regresi data panel yang dipilih dengan melakukan uji Chow dan Hausman, uji-f, uji-t, dan uji koefisien determinasi $\left(R^{2}\right)$.

\section{HASIL DAN PEMBAHASAN}

\section{Uji multikolinieritas}

Tabel 2. Hasil uji multikolinieritas

Sumber: Diolah penulis menggunakan Eviews 9

\begin{tabular}{|c|c|c|c|c|}
\hline & LnINF & LnSB & LnNT & LnROA \\
\hline LnINF & 1 & 0,560351 & $-0,075375$ & 0,200034 \\
\hline LnSB & 0,560351 & 1 & 0,696252 & 0,150391 \\
\hline LnNT & $-0,075375$ & 0,696252 & 1 & 0,026959 \\
\hline LnROA & 0,200034 & 0,150391 & 0,026959 & 1 \\
\hline
\end{tabular}

Berdasarkan pada Tabel 2, hasil uji multikolinieritas menunjukkan bahwa koefisien korelasi antar variabel independen pada penelitian ini memiliki nilai korelasi di bawah 0,8 , artinya tidak terjadi multikolinieritas pada persamaan regresi dalam penelitian ini.

\section{Analisis statistik deskriptif}

Tabel 3. Hasil uji statistik deskriptif

Sumber: Diolah penulis menggunakan Eviews 9

\begin{tabular}{|l|c|c|c|c|c|}
\hline & LnHS & LnINF & LnSB & LnNT & LnROA \\
\hline Mean & 8,362990 & $-3,595286$ & $-3,059567$ & 9,536372 & $-2,838058$ \\
\hline Median & 8,335671 & $-3,499913$ & $-3,047026$ & 9,534781 & $-2,796881$ \\
\hline Maximum & 11,33619 & $-3,321462$ & $-2,813411$ & 9,585552 & $-0,770028$ \\
\hline Minimum & 5,438079 & $-4,086376$ & $-3,283414$ & 9,508740 & $-6,645391$ \\
\hline Std. Dev. & 1,173290 & 0,262712 & 0,158494 & 0,027711 & 1,083389 \\
\hline Skewness & 0,121649 & $-1,057223$ & 0,152382 & 0,789505 & $-0,826412$ \\
\hline Kurtosis & 3,065725 & 2,734382 & 2,024632 & 2,340598 & 4,118444 \\
\hline Jarque-Bera & 0,357267 & 25,54555 & 5,873756 & 16,47049 & 22,40291 \\
\hline Probability & 0,836412 & 0,000003 & 0,053031 & 0,000265 & 0,000014 \\
\hline Sum & 1129,004 & $-485,3635$ & $-413,0415$ & 1287,410 & $-383,1378$ \\
\hline Sum Sq. Dev. & 184,4656 & 9,248329 & 3,366125 & 0,102902 & 157,2801 \\
\hline Observations & 135 & 135 & 135 & 135 & 135 \\
\hline
\end{tabular}

Pada Tabel 3 yaitu hasil uji statistik deskriptif, variabel harga saham dan nilai tukar/kurs memiliki variasi data yang rendah karena nilai standar deviasi berada di bawah rata-rata, sedangkan variabel inflasi, suku bunga dan ROA memiliki variasi data yang tinggi. 
Estimasi model data panel

Tabel 4. Hasil uji Chow

Sumber: Diolah Penulis menggunakan Eviews 9

\begin{tabular}{|l|c|c|c|}
\hline \multicolumn{1}{|c|}{ Effect Test } & Statistic & d.f. & Prob. \\
\hline Cross-section F & 114,272453 & $(26,104)$ & 0.0000 \\
\hline Cross-section Chi-square & 457,204031 & 26 & 0.0000 \\
\hline
\end{tabular}

Berdasarkan hasil uji Chow pada Tabel 4, nilai dari probability value chi square adalah sebesar 0,0000, yang berarti lebih kecil dari 0,05. Hasil ini menandakan bahwa berdasarkan uji Chow, model regresi data panel yang paling tepat digunakan antara Common Effect Model dan Fixed Effect Model adalah Fixed Effect Model (FEM). Selanjutnya, akan dilanjutkan dengan uji Hausman.

Tabel 5. Hasil uji Hausman

Sumber: Diolah Penulis Menggunakan Eviews 9

\begin{tabular}{|l|c|c|c|}
\hline Test Summary & Chi-Sq. Statistic & Chi-Sq. d.f. & Prob. \\
\hline Cross-section random & 0,000000 & 4 & 1,0000 \\
\hline
\end{tabular}

Berdasarkan hasil uji Hausman pada Tabel 5, nilai dari probability value chi square adalah sebesar 1,0000. Hasil ini lebih besar dari 0,05. Hasil ini menandakan bahwa berdasarkan uji Hausman, model regresi yang paling tepat digunakan antara Random Effect Model dan Fixed Effect Model adalah Random Effect Model (REM).

\section{Analisis regresi data panel}

Tabel 6. Hasil Estimasi Random Effect Model

Sumber: Diolah Penulis Menggunakan Eviews 9

\begin{tabular}{|c|c|c|c|c|}
\hline Variable & Coefficient & Std. Error & t-Statistic & Prob. \\
\hline $\mathrm{C}$ & $-10,61534$ & 16,28830 & $-0,651716$ & 0,5157 \\
\hline LnINF & 0,363966 & 0,154048 & 2,362671 & 0,0196 \\
\hline LnSB & $-0,635438$ & 0,348102 & $-1,825439$ & 0,0702 \\
\hline LnNT & 1,949266 & 1,652172 & 1,179821 & 0,2402 \\
\hline \multirow[t]{3}{*}{ LnROA } & 0,086750 & 0,042894 & 2,022413 & 0,0452 \\
\hline & \multicolumn{2}{|c|}{ Effects Specification } & & \\
\hline & & & S.D. & Rho \\
\hline \multicolumn{3}{|l|}{ Cross-section random } & 1,143621 & 0,9589 \\
\hline \multicolumn{3}{|l|}{ Idiosyncratic random } & 0,236621 & 0,0411 \\
\hline & \multicolumn{2}{|c|}{ Weighted Statistics } & & \\
\hline R-squared & 0,101793 & \multicolumn{2}{|c|}{ Mean dependent var } & 0,770541 \\
\hline Adjusted R-squared & 0,074156 & \multicolumn{2}{|c|}{ S.D. dependent var } & 0,246009 \\
\hline S.E. of regression & 0,236712 & \multicolumn{2}{|c|}{ Sum squared resid } & 7,284235 \\
\hline F-statistic & 3,683193 & \multicolumn{2}{|c|}{ Durbin-Watson stat } & 1,291464 \\
\hline Prob(F-statistic) & 0,007100 & & & \\
\hline
\end{tabular}

Berdasarkan Tabel 6, hasil uji regresi data panel dengan Random Effect Model (REM), maka dapat dibentuk suatu persamaan pada penelitian ini, yaitu sebagai berikut:

LnHS $=-10,6154+0,3640 * \operatorname{LnINF}-0,635438 * \operatorname{LnSB}+1,9493 * \operatorname{LnNT}+0,0868 * \operatorname{LnROA}$

\section{Uji-F}

Berdasarkan Tabel 6, hasil Uji-F menunjukkan bahwa nilai probabilitas $F$-statistic sebesar 0,007100, bernilai lebih kecil dari 0,05. Hasil tersebut menandakan bahwa tingkat inflasi, tingkat 
suku bunga, kurs/nilai tukar dan Return on Asset (ROA) secara bersama-sama dapat mempengaruhi harga saham.

\section{Uji-t}

Berdasarkan hasil uji-t pada Tabel 6, dapat dijelaskan apakah terdapat atau tidak pengaruh yang signifikan dari setiap variabel independen terhadap variabel dependen. Variabel inflasi dan ROA memiliki nilai probabilitas di bawah 0,05 , sehingga dapat disimpulkan variabel inflasi dan ROA memiliki pengaruh signifikan terhadap harga saham.

Kemudian, variabel suku bunga dan nilai tukar/kurs memiliki nilai probabilitas di atas 0,05, sehingga dapat disimpulkan variabel suku bunga dan nilai tukar/kurs tidak memiliki pengaruh signifikan terhadap harga saham.

\section{Uji Koefisien Determinasi $\left(\mathbf{R}^{2}\right)$}

Berdasarkan hasil uji pada Tabel 6, Nilai Adjusted R-squared $\left(\mathrm{R}^{2}\right)$ adalah sebesar 0,074156 atau $7,42 \%$. Dari hasil tersebut, artinya sebesar 7,42\% harga saham dapat dijelaskan oleh variabel tingkat inflasi, tingkat suku bunga, nilai tukar dan Return on Asset (ROA). Sisanya sebesar $92,58 \%$ dijelaskan oleh variabel lain di luar penelitian ini.

\section{Diskusi}

Berdasarkan uji yang telah dilakukan, secara bersama-sama tingkat inflasi, tingkat suku bunga, kurs/nilai tukar dan Return on Asset (ROA) mempengaruhi harga saham. Akan tetapi secara parsial, tidak semua variabel berpengaruh terhadap harga saham.

Inflasi merupakan kenaikan harga barang dan jasa secara umum atau keseluruhan. Pada penelitian ini, ditemukan bahwa tingkat inflasi memiliki hubungan positif dan signifikan terhadap harga saham. Hasil pada penelitian ini sejalan dengan penelitian Utomo dkk. (2019). Tingkat inflasi di Indonesia masih tergolong rendah, yaitu bernilai dibawah 10\%, sehingga tidak terlalu memberikan dampak negatif terhadap perekonomian di Indonesia karena pasar masih bisa mentoleransi tingkat inflasi yang masih tergolong rendah. Berdasarkan temuan pada penelitian ini, sebaiknya investor tidak perlu terlalu sensitif dengan pergerakan tingkat inflasi di Indonesia karena inflasi di Indonesia tergolong ke dalam inflasi tingkat rendah. Kemudian inflasi yang memiliki dampak positif terhadap harga saham perusahaan yang tergabung dalam indeks LQ45 menandakan bahwa perusahaan-perusahaan telah mempersiapkan dan memiliki kebijakan yang tepat dalam merespons pergerakan tingkat inflasi di Indonesia. Bagi perusahaan, sebaiknya merencanakan dan mengembangkan kebijakan dengan baik atas perubahan pada tingkat inflasi, agar inflasi tidak memberikan dampak negatif terhadap harga saham.

Tingkat suku bunga merupakan kebijakan moneter yang ditetapkan oleh pemerintah dalam mengatur jumlah uang beredar. Pada penelitian ini, ditemukan bahwa tingkat suku bunga tidak memiliki pengaruh yang signifikan terhadap harga saham. Hasil pada penelitian ini sejalan dengan penelitian Subing dkk. (2017) dan Saputra dkk. (2019). Tingkat suku bunga cukup stabil, sehingga para investor tidak mengalami kecemasan mengenai investasi yang mereka lakukan di saham dan perubahan pada suku bunga tidak mempengaruhi harga saham. Berdasarkan temuan pada penelitian ini, investor sebaiknya menyesuaikan diri dengan tingkat risiko yang mereka miliki, karena dengan meningkatnya atau menurunnya tingkat suku bunga tidak memiliki dampak pasti karena terdapat pengaruh positif maupun negatif terhadap harga saham, sehingga belum tentu memiliki pengaruh langsung terhadap harga saham. Kemudian bagi perusahaan, kenaikan atau penurunan tingkat suku bunga sebaiknya dimanfaatkan dengan sebaik-baiknya. 
Pada perusahaan perbankan, kenaikan suku bunga dapat dimanfaatkan untuk meningkatkan kinerja perusahaan. Kemudian ketika suku bunga turun, perusahaan dapat melakukan pinjaman dengan suku bunga yang lebih rendah.

Kurs merupakan nilai mata uang suatu negara jika dibandingkan dengan mata uang negara lain. Pada penelitian ini, ditemukan bahwa nilai tukar atau kurs tidak berpengaruh signifikan terhadap harga saham. Hasil penelitian ini sejalan dengan penelitian Saputra dkk. (2019). Pada periode pengamatan, kurs stabil atau tidak pernah mengalami kenaikan atau penurunan yang signifikan. Kemudian perusahaan juga memiliki kinerja yang baik, sehingga kepercayaan investor akan perusahaan tetap terjaga dan saham tidak terkena dampak dari nilai tukar. Berdasarkan temuan pada penelitian ini, investor sebaiknya memperhatikan perusahaan tempat mereka berinvestasi, apakah perusahaan itu bergantung dengan impor bahan baku atau perusahaan itu melakukan ekspor. Kemudian bagi perusahaan, sebaiknya memanfaatkan perubahan harga saham yang terjadi, dengan membuat kebijakan mengenai impor atau ekspor yang dilakukan demi menjaga kinerja perusahaan.

Return on Asset (ROA) merupakan rasio yang mengukur kemampuan perusahaan dalam menghasilkan laba dari kontribusi aset yang dimilikinya. Pada penelitian ini, ditemukan bahwa ROA memiliki pengaruh positif dan signifikan terhadap harga saham. Hasil pada penelitian ini sejalan dengan penelitian Subing dkk. (2017). Ketika ROA meningkat, artinya perusahaan mampu menghasilkan laba atas kontribusi dari aset yang dimilikinya, sehingga berpengaruh terhadap harga saham. Berdasarkan temuan pada penelitian ini, sebaiknya investor menggunakan Return on Asset (ROA) sebagai salah satu indikator untuk melakukan investasi, karena Return on Asset (ROA) yang meningkat menandakan kinerja perusahaan baik, sehingga dapat meningkatkan harga saham. Kemudian bagi perusahaan, dapat memanfaatkan aset yang dimiliki dengan sebaik-baiknya untuk menghasilkan laba yang sesuai dengan aset yang di kontribusikan, sehingga nilai perusahaan meningkat dan memberikan sinyal positif mengenai perusahaan terhadap investor.

\section{KESIMPULAN DAN SARAN Simpulan}

Berdasarkan hasil pada penelitian ini, dapat disimpulkan bahwa, secara bersama-sama tingkat inflasi, tingkat suku bunga, kurs/nilai tukar dan Return on Asset (ROA) memiliki pengaruh terhadap harga saham.

Kemudian secara parsial, hanya inflasi dan Return on Asset (ROA) yang memiliki pengaruh terhadap harga saham, sedangkan tingkat suku bunga dan nilai tukar/kurs tidak memiliki pengaruh terhadap harga saham.

\section{Saran}

Bagi penelitian selanjutnya disarankan untuk menambahkan variabel-variabel lainnya di luar penelitian ini, baik dari faktor internal perusahaan maupun faktor eksternal perusahaan yang mempengaruhi harga saham dikarenakan berdasarkan uji Adjusted $R$-square $\left(\mathrm{R}^{2}\right)$, masih banyak variabel di luar penelitian ini yang mampu menjelaskan harga saham. Kemudian periode waktu pada penelitian bisa dibuat lebih lama untuk mengetahui kondisi pasar modal yang sesungguhnya. 
Bagi pihak perusahaan, penelitian ini dapat dijadikan sebagai referensi untuk lebih memperhatikan faktor internal dan eksternal perusahaan yang dapat mempengaruhi harga saham, sehingga perusahaan dapat memutuskan kebijakan yang tepat untuk menjaga kestabilan harga saham.

Bagi pihak investor, penelitian ini bisa dijadikan sumber informasi dan dasar pengambilan keputusan investasi, sehingga keputusan investasi yang dilakukan bisa lebih tepat.

\section{REFERENSI}

Al-Sartawi, A. M., \& Reyad, S. (2018). Signaling theory and the determinants of online financial disclosure. Journal of Economic and Administrative Sciences, 34(3), 237-247.

Andriani, F. (2013). Pengambilan Keputusan Investasi Saham Dengan Menggunakan Analisis Fundamental Internal Melalui Pendekatan Analisis Fundamental Internal Melalui Pendekatan Price Earning Ratio (Studi Pada Perusahaan Otomotif Dan Komponennya Yang Listing Di Bursa Efek Indon. Jurnal Administrasi Bisnis, 5(2).

Chang, B. H., Meo, M. S., Syed, Q. R., \& Abro, Z. (2019). Dynamic analysis of the relationship between stock prices and macroeconomic variables: An empirical study of Pakistan stock exchange. South Asian Journal of Business Studies, 8(3).

Chen, N. (1983). Some empirical tests of the theory of arbitrage pricing. The Journal of Finance, 38(5), 1393-1414.

Ghozali, I. (2016). Aplikasi Analisis Multivariete Dengan Program IBM SPSS. Semarang: Badan Penerbit Universitas Diponegoro.

Hongbing, O., \& Fadli, F. (2020). Can Financial Ratio Change Stock Price? (LQ 45 Index Case Study For 2010-2018). International Journal of Information, Business and Management, 12(2).

Ibrahim, M. I., Titaley, J., \& Manurung, T. (2017). Analisis Keakuratan Capital Asset Pricing Model (CAPM) dan Arbitrage Pricing Theory (APT) dalam Memprediksi Expected Saham pada LQ45. d'CARTESIAN, 6(1), 30-44.

IDX. (2021). "Indeks". https://www.idx.co.id/produk/indeks/, diakses 27 Juli 2021.

Ivan. (2018). Analisis Pengaruh Faktor-Faktor Fundamental Terhadap Harga Saham (Studi Empiris Pada Perusahaan Manufaktur Yang Terdaftar di Bursa Efek Indonesia Periode 2012 - 2015). Jurnal Muara Ilmu Ekonomi dan Bisnis, 2(1), 254.

Juwana, C. (2015). Studi perbandingan metode CAPM dan APT pada perusahaan sektor manufaktur yang terdaftar di Bursa Efek Indonesia periode 2008-2013. Kajian Ilmiah Mahasiswa Manajemen.

Kurniasih, A., \& Johannes, L. D. Y. (2015). Analisis Variabel Makroekonomi Terhadap Kinerja Reksadana Campuran. Jurnal Manajemen, 19(1), 136-151.

Nuryasman, M. N., \& Permatasari, V. (2016). Dampak Variabel Makroekonomi Dan Indeks Saham Global Terhadap Indeks Harga Lq45 Di Bursa Efek Indonesia. Jurnal Ekonomi, 21(3), 309-324.

Nuryasman, \& Yessica. (2017). Determinan harga saham sektor properti dan real estat di bursa efek indonesia. Jurnal Manajemen, 21(2), 270-281.

Saputra, I., Veny, V., \& Mayangsari, S. (2019). Pengaruh Rasio Keuangan, Aksi Korporasi Dan Faktor Fundamental Ekonomi Makro Terhadap Harga Saham. Jurnal Magister Akuntansi Trisakti, 5(1).

Stiglitz, J. E. (2000). The contributions of the economics of information to twentieth century economics. The quarterly journal of economics, 115(4), 1441-1478.

Subing, H. J. T., Wedi Rusmawan Kusumah, R., \& Gusni. (2017). An empirical analysis of 
internal and external factors of stock pricing: Evidence from Indonesia. Problems and Perspectives in Management, 15(4).

Syahyunan. (2015). Manajemen Keuangan: Perencanaan, Analisis, dan Pengendalian Keuangan. Medan: USU Press.

Utomo, S. H., Wulandari, D., Narmaditya, B. S., Handayati, P., \& Ishak, S. (2019). Macroeconomic factors and LQ45 stock price index: Evidence from Indonesia. In Investment Management and Financial Innovations, 16(3), hal. 251-259.

Yahoo Finance. (2021). "Data Historis Indeks LQ45". https://finance.yahoo.com/quote/\%5EJKLQ45?p=\%5EJKLQ45, diakses 27 Juli 2021. 